\title{
EVALUASI DAMPAK PENGGUNAAN BAHAN KIMIA SELAMA KEGIATAN PEMUGARAN CANDI BRAHU
}

\author{
Ira Fatmawati \\ Balai Pelestarian Cagar Budaya Jawa Timur \\ Email : ira_fatmawati_chem@yahoo.com
}

\begin{abstract}
Abstrak : Candi Brahu merupakan salah satu bangunan yang telah ditetapkan sebagai cagar budaya peringkat nasional. Candi ini telah dilakukan dua kali pemugaran, yaitu : masa kolonial Belanda dan masa pemerintah Indonesia. Berdasarkan laporan hasil pemugaran tahun 1991-1995 tercatat ada empat bahan kimia yang diaplikasikan pada bangunan candi, yaitu : Silicosol yang berfungsi sebagai bahan pelindung, Araldite tar sebagai bahan kedap air, serta AC 322 dan Hyvar XL sebagai bahan herbisida. Kegiatan pemugaran kedua ini telah berlalu lebih dari 20 tahun dan belum pernah dievaluasi. Tujuan dari kegiatan ini untuk mengetahui dampak yang ditimbulkan dari penggunaan bahan kimia selama kegiatan pemugaran kedua. Kegiatan ini dilakukan dengan melakukan pengamatan secara langsung di Candi Brahu kemudian mendata jenis bata, letak aplikasi bahan kimia, serta dampak yang ditimbulkan dari penggunaan bahan tersebut dengan cara mendata jenis kerusakan. Hasilnya, bata penyusun candi terdiri dari tiga jenis, yaitu : bata lama, bata lama yang dipasang kembali ketika pemugaran Belanda, dan bata hasil pemugaran tahun 1991-1995. Aplikasi bahan Silicosol hanya dilakukan pada kaki I dan kaki II. Araldite tar diaplikasikan pada bagian bawah bata yang dianggap lantai, batas bata hasil pemugaran tahap I dan tahap II, serta di atas dan samping lapisan cor beton. Untuk aplikasi AC 322 dan Hyvar XL hanya dilakukan pada tahap III di bagian tubuh sedangkan aplikasi pada bagian lain dari bangunan candi tidak ditemukan datanya. Dengan demikian dapat disimpulkan bahwa bata hasil pemugaran tahun 1991-1995 cenderung rapuh sedangkan dua jenis bata lainnya tampak utuh. Bahan Silicosol dioles pada seluruh permukaan bata bagian kaki I dan kaki II, namun pengelupasan dan kerapuhan bata lebih banyak terjadi pada bata hasil pemugaran tahun 1991-1995. Ini menandakan kerusakan itu bukan akibat penggunaan bahan Silicosol tetapi karena kualitas bata yang kurang bagus. Aplikasi bahan Araldite tar masih efektif terlihat pada struktur bata yang tidak mengalami kerusakan. Efektivitas bahan AC 322 dan Hyvar XL tidak dapat bertahan lama sehingga tidak dapat diamati dampaknya terhadap bangunan candi. Evaluasi dampak penggunaan bahan kimia setelah kegiatan konservasi dan kajian untuk mencari solusi penanganan kerusakan perlu dilakukan untuk mencegah kerusakan semakin luas.
\end{abstract}

Kata kunci : Candi Brahu, pemugran, bahan kimia

Abstract : Brahu Temple is one of the buildings that has been designated as a national cultural heritage. This temple has been done two times restoration in the Dutch colonial period and the Indonesian government. Based on the results of the restoration of 1991-1995, there were four chemicals applied to the temple by Silicosol that serves as a protective material, Araldite tar as waterproof material, AC 322 and Hyvar XL as herbicide material. This second restoration activity has passed more than 20 years and has never been evaluated. The purpose of this activity is to know the impact of chemical use during the second restoration activity. This activity is done by direct observation in Brahu Temple and then record the type of brick, the location of chemical applications, as well as the impact caused by the use of such materials by collecting the type of damage. As a result, the temple brick consists of three types by old bricks, old bricks reassembled during Dutch restoration, and brick restoration results 1991-1995. Silicosol application is only done on Leg I and Leg II. Araldite tar is applied to the bottom of the brick which is considered to be the floor, brick boundary of the restoration of Stage I and Stage II, as well as on top and side of the concrete cast layer. For applications AC 322 and Hyvar XL only done in Phase III in the Body while the application on other parts of the temple building is not found data. Thus it can be concluded that the restoration bricks of 1991-1995 tend to be fragile while the other two types of bricks appear intact. Silicosol was applied to all the brick surfaces of leg I and leg II, but the exfoliation and brickness was more prevalent in the restoration bricks of 1991-1995. This indicates that the damage is not due to the use of Silicosol but due to 
the poor quality of the brick. The application of Araldite tar is still effectively seen in brick structures that are not damage. The effectiveness of AC 322 and Hyvar XL can not last long so that they can't be observed impact on the building of the temple. Evaluation of the impact of the use of chemicals after conservation activities and studies to find a solution to the treatment of damage needs to be done to prevent widespread damage.

Keyword : Candi Brahu, restoration, chemicals

\section{PENDAHULUAN}

\section{A. Latar Belakang}

Mojokerto yang diperkirakan merupakah wilayah bekas tinggalan Kerajaan Majapahit memiliki sejumlah cagar budaya yang sebagian besar tersusun atas bata. Salah satu bangunan cagar budayanya yang masih berdiri kokoh hingga saat ini adalah Candi Brahu. Candi ini terletak di Dusun Bejijong, Desa Bejijong, Kecamatan Trowulan, Kabupaten Mojokerto tepatnya pada koordinat 651610,559 - 9165999,999. Pada tahun 1998, Candi Brahu telah ditetapkan sebagai Cagar Budaya Peringkat Nasional oleh Menteri Kebudayaan dan Pariwisata dengan Surat Keputusan Nomor : 177/M/1998 tertanggal 21 Juli 1998. Penetapan sebagai cagar budaya peringkat nasional tidak hanya diberikan pada bangunan Candi Brahu saja tetapi wilayah Trowulan di mana candi tersebut berada, juga telah ditetapkan sebagai Kawasan Cagar Budaya Peringkat Nasional berdasarkan Surat Keputusan Menteri Pendidikan dan Kebudayaan Nomor : 260/M/2013 tertanggal 30 Desember 2013.

Dalam riwayat penanganannya, Candi Brahu telah mengalami pemugaran pada masa kolonial Belanda sekitar tahun 1920 dan masa pemerintah Indonesia yang dilaksanakan oleh Departemen Pendidikan dan Kebudayan melalui Proyek Pembinaan Peninggalan Sejarah dan Kepurbakalaan Bekas Kota Kerajaan Majapahit tahun 1991-1995. Kegiatan pemugaran Candi Brahu telah berlalu hampir 23 tahun, namun dampak penggunaan bahan kimia selama kegiatan tersebut belum pernah dilakukan evaluasi meskipun setiap tahunnya telah diobservasi kerusakannya. Dalam upaya mendata kembali hasil kegiatan pemugaran dan menganalisis penyebab kerusakan yang saat ini terjadi, maka perlu dilakukan evaluasi mengenai dampak bahan kimia yang telah diaplikasikan pada bangunan candi tersebut.

\section{B. Tujuan}

Kegiatan evaluasi pasca pemugaran Candi Brahu bertujuan untuk :

1. Mendata kembali hasil kegiatan pemugaran tahun 1991-1995.

2. Mengetahui dampak negatif yang ditimbulkan dari penggunaan bahan kimia selama kegiatan pemugaran tahun 1991-1995.

3. Mengetahui efektivitas penggunaan bahan Silicosol, Araldite tar, AC 322, dan Hyvar XL yang diaplikasikan selama kegiatan pemugaran tahun 1991-1995.

\section{Manfaat}

Manfaat dari kegiatan evaluasi pasca pemugaran Candi Brahu adalah dapat mengetahui dampak yang ditimbulkan akibat aplikasi bahan kimia sehingga tingkat keefektivannya menjadi referensi dalam penentuan bahan untuk kegiatan selanjutnya. Dengan demikian diharapkan dapat mempermudah analisis dalam mencari faktor penyebab kerusakan bata yang saat ini semakin meluas.

\section{PEMBAHASAN}

\section{A. Tinjauan Pustaka}

Candi Brahu merupakan salah satu candi di Kawasan Cagar Budaya Trowulan yang telah dilakukan pemugaran. Kegiatan pemugaran pada candi ini berlangsung selama dua kali, yaitu : masa kolonial Belanda dan masa pemerintahan Indonesia. Pada pemugaran terakhir yang dilaksanakan sekitar tahun 1991-1995 hanya bersifat parsial, artinya : bata yang masih dalam kondisi baik tetap dipertahankan sedangkan bata yang rapuh diganti dengan bata baru. Kegiatan pemugaran yang dilakukan oleh Belanda masih menggunakan bata lama, namun ditambahkan spesi. Untuk memudahkan dalam mengidentifikasi dampak dari dua kegiatan pemugaran yang telah berlangsung, maka digunakan istilah bata lama, 
bata hasil pemugaran Belanda, dan bata hasil pemugaran tahun 1991-1995.
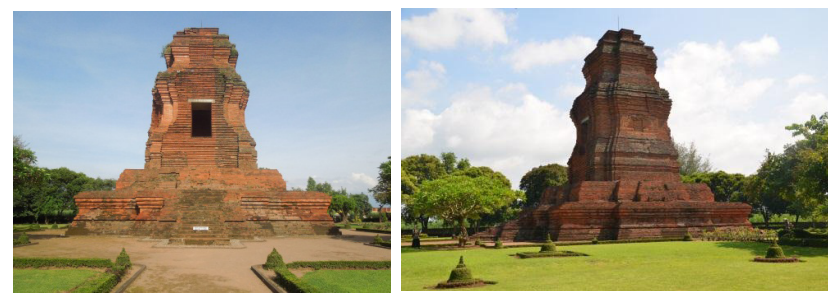

Foto 1. Candi Brahu tampak barat (kiri) dan tampak barat daya (kanan)

Sumber : Dokumentasi penulis

Bangunan cagar budaya Candi Brahu terbagi menjadi empat bagian, yaitu : kaki I, kaki II, tubuh, dan atap. Kaki I berada pada lapis 1-50, kaki II berada pada lapis 51-114, tubuh berada pada lapis 115-173, dan atap berada pada lapis 174-284. Selama kegiatan pemugaran tahun 1991-1995, selain mengganti bata yang rusak juga dilakukan pembersihan dan perawatan menggunakan bahan kimia. Beberapa bahan kimia yang digunakan adalah :

\section{Silicosol}

Silicosol merupakan bahan kimia berupa cairan tak berwarna yang memiliki rumus kimia SiO2.0,5H2O. Bahan yang berfungsi sebagai pelindung ini digunakan untuk mencegah air hujan meresap ke permukaan bata. Silicosol biasanya diaplikasikan pada permukaan dinding bagian luar. Aplikasi yang kurang tepat dapat menimbulkan kerusakan pada bata berupa pengelupasan dan kerapuhan. Hal ini disebabkan bahan Silicosol yang sifatnya sebagai bahan pelindung atau penolak air (water repellent) menyebabkan air yang berada di dalam material bata menjadi terhambat untuk keluar, istilahnya : "bata sulit bernafas". Secara normal, air yang berada di dalam material akan menguap melalui permukaan akibat pengaruh suhu udara, sinar matahari, dan angin. Adanya lapisan Silicosol di permukaan material menyebabkan terjadinya dorongan dari dalam akibat akumulasi air sehingga bata menjadi mengelupas dan akhirnya rapuh. Inilah alasan mengapa bahan Silicosol dihentikan penggunaannya.

\section{Araldite Tar}

Dalam Laporan Hasil Pelaksanaan Kegiatan
Pemugaran Candi Brahu tidak menyebutkan mengenai spesifikasi Araldite tar. Namun berdasarkan hasil pencarian pada laman Borobudurpedia diperoleh deskripsi bahwa Araldite tar adalah merek dagang bahan pelapis kedap air. Berbentuk cairan kental yang tersusun atas dua komponen, dicampur secara homogen sesaat sebelum digunakan. Araldite tar merupakan polimer berbahan epoksi resin yang dimodifikasi dengan campuran tar.

Epoksi bersifat kuat, tahan lama, dan stabil oleh kondisi lingkungan, namun kaku dan getas (dapat patah) pada tekanan tinggi. Tar merupakan hasil samping pengolahan minyak bumi yang kental berwarna hitam. Pencampuran tar ke dalam epoksi akan meningkatkan sifat elastisitas sehingga cocok digunakan sebagai bahan kedap air. Apabila diaplikasikan pada struktur/bangunan, Araldite tar akan mengikat kuat namun elastis mengikuti pergerakan yang terjadi. Sifat yang kuat dan elastis membuat Araldite tar mampu menjadi bahan pelapis yang kedap air dan tidak mudah bocor jika terjadi pergerakan akibat kembang susut atau pergeseran struktur.

\section{AC 322 dan Hyvar XL}

Bahan AC 322 dan Hyvar XL digunakan untuk menangani masalah yang disebabkan oleh pengaruh pertumbuhan tanaman. AC 322 berfungsi untuk menghambat pertumbuhan lichenes (lumut kerak) sedangkan Hyvar XL merupakan bahan herbisida yang berfungsi untuk membasmi/mencegah tumbuhnya kembali lumut. Bahan AC 322 yang masih digunakan hingga saat ini merupakan campuran dari lima komponen bahan, terdiri dari : Amonium bikarbonat, Sodium bikarbonat, Carboxy methyl cellulose, EDTA, dan Arkopal.

Berbeda dengan AC 322, informasi mengenai Hyvar XL tidak banyak karena dalam Laporan Hasil Pelaksanaan Kegiatan Pemugaran tidak mencantumkan spesifikasinya dan bahan tersebut kini sudah tidak dipakai lagi. Berdasarkan deskripsi dari produk DuPont yang memiliki nama dagang Hyvar XL yang kemungkinan besar merupakan produk yang hampir sama dengan Hyvar XL yang digunakan saat kegiatan pemugaran di Candi Brahu menyebutkan bahwa Hyvar XL merupakan cairan berwarna kuning, berbau seperti alkohol, memiliki pH 11,2-12,2, dan larut dalam air. Bahan ini mengandung 
Bromacil (5-bromo-3-sec-butyl-6-methyluracil) dan Lithium salt of Bromacil (5-bromo-3-sec-butyl-6methylpyrimidine-2,4(1H,3H)-dione).

\section{B. Data Hasil Evaluasi}

Berdasarkan data dari Laporan Hasil Pelaksanaan Kegiatan Pemugaran Candi Brahu tahun 1991-1995, penggantian bata hanya dilakukan secara parsial pada bagian yang mengalami kerusakan dan mempertahankan bata yang kondisinya masih utuh. Hasilnya, bangunan setinggi 21,80 meter ini terlihat warna batanya tidak seragam. Dalam pengumpulan data dari laporan tersebut tidak ditemukan Laporan Hasil Pelaksanaan Kegiatan Pemugaran Candi Brahu Tahap I sehingga data yang dicantumkan merupakan hasil pemugaran tahap II - V. Data jenis bata pada setiap bagian candi disajikan pada tabel di bawah ini.

Tabel 1 : Data jenis bata Candi Brahu, Kab. Mojokerto

\begin{tabular}{|c|c|c|c|c|c|}
\hline \multirow{2}{*}{$\mathbf{~ H o . ~}$} & \multirow{2}{*}{ Sisi } & \multirow{2}{*}{ Beginn } & \multicolumn{3}{|c|}{ Jens Betr } \\
\hline & & & 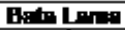 & Bata Belonda & Batm y - -95 \\
\hline 1 & Bent: & Kali I & $\sqrt{ }$ & - & $\sqrt{ }$ \\
\hline$\overline{2}$ & B: & KFikill & $\sqrt{ }$ & - & $\sqrt{ }$ \\
\hline 3 & Befrat & Tibuh & - & $\sqrt{ }$ & $\sqrt{ }$ \\
\hline 4 & Barat & Atap & - & $\sqrt{ }$ & $\sqrt{ }$ \\
\hline 5 & Utarn & Kali I I & $\sqrt{ }$ & - & $\sqrt{ }$ \\
\hline 6 & Ut:ary & KFki II & $\checkmark$ & - & $T$ \\
\hline 7 & Uttery & Tubul & $\sqrt{ }$ & $\sqrt{ }$ & $\sqrt{ }$ \\
\hline$\overline{8}$ & Ut:ary & Atap & T & $\sqrt{ }$ & $\sqrt{ }$ \\
\hline $\mathbf{9}$ & Trmur & K=ki I & $\sqrt{ }$ & - & $\sqrt{ }$ \\
\hline 10 & Trmar & Kaki II & $\sqrt{ }$ & - & $\sqrt{ }$ \\
\hline 11 & Trmur & Tubuh & $\sqrt{ }$ & $\sqrt{ }$ & $\sqrt{ }$ \\
\hline 12 & Trmur & Atrip & $\sqrt{ }$ & $\sqrt{ }$ & - \\
\hline 13 & Setolan & Kali I & $\checkmark$ & - & $\sqrt{ }$ \\
\hline 14 & Setriten & Kaki II & $\sqrt{ }$ & - & $\sqrt{ }$ \\
\hline 15 & Setgitn & Tubul & $\sqrt{ }$ & $\sqrt{ }$ & - \\
\hline 16 & Setron & Atap & - & $\sqrt{ }$ & - \\
\hline
\end{tabular}

Sumber : Dokumen Penulis

Dalam kegiatan pemugaran tahun 1991-1995, selain melakukan penggantian bata juga dilakukan beberapa upaya pencegahan terhadap kerusakan akibat faktor lingkungan, antara lain : berupa pelapisan cor beton dan penggunaan bahan kimia. Untuk bahan kimia yang digunakan ada empat jenis, yaitu : Silicosol, Araldite tar, AC 322, dan Hyvar XL. Keempat bahan tersebut dapat dijelaskan sebagai berikut :

1. Silicosol

Bahan ini digunakan pada kegiatan Proyek Pelestarian/Pemanfaatan Peninggalan Sejarah dan Purbakala Bekas Kota Kerajaan Majapahit, meliputi :
Candi Brahu, Gapura Wringin Lawang, Candi Tikus, Candi Bajangratu, Kolam Segaran, dan Candi Kedaton. Namun kini, bahan tersebut tidak digunakan karena dapat menimbulkan dampak negatif terutama bagi cagar budaya yang masih mengalami proses kapilarisasi air. Berdasarkan Laporan Hasil Pelaksanaan Kegiatan Pemugaran Candi Brahu tahun 1991-1995 diperoleh data aplikasi bahan Silicosol seperti terlihat pada tabel di bawah ini.

Tabel 2 : Data letak aplikasi bahan Silicosol pada Candi Brahu

\begin{tabular}{|c|c|c|l|}
\hline No. & Tahap & Tahun & \multicolumn{1}{|c|}{ Bagian Candi yang Dioles } \\
\hline 1 & III & $1992 / 1993$ & Kaki I sisi barat lapis 37 - 50 dan 42 -50 \\
\hline 2 & III & $1992 / 1993$ & Kaki I sisi utara dan timur lapis 37 -50 \\
\hline 3 & III & $1992 / 1993$ & Kaki I sisi selatan lapis 37 - 50 dan 42 - 49 \\
\hline 4 & III & $1992 / 1993$ & $\begin{array}{l}\text { Kaki II sisi barat, utara, timur, dan selatan lapis } \\
51-67 \text { dan 70 - 74 }\end{array}$ \\
\hline 5 & III & $1992 / 1993$ & $\begin{array}{l}\text { Dinding Kaki II lapis 68 - 70 pengolesan } \\
\text { Silicosol ditangguhkan }\end{array}$ \\
\hline 6 & IV & $1993 / 1994$ & $\begin{array}{l}\text { Kaki II sisi barat, utara, timur, dan selatan lapis } \\
75-96\end{array}$ \\
\hline 7 & V & $1994 / 1995$ & $\begin{array}{l}\text { Kaki I sisi barat, utara, timur, dan selatan lapis } \\
12-26\end{array}$ \\
\hline
\end{tabular}

Untuk mengetahui dampak dari penggunaan bahan kimia yang telah dilakukan selama kegiatan pemugaran, maka perlu dilakukan pendataan jenis kerusakan yang terjadi saat ini. Dari hasil observasi bulan Maret 2018 diketahui bahwa jenis kerusakan yang dijumpai pada Candi Brahu disebabkan oleh faktor kimia, biologi, fisik, dan manusia. Kerusakan akibat faktor kimia yang terjadi pada bata dapat berupa penggaraman, mengelupas, dan rapuh. Data kerusakan akibat faktor kimia yang dijumpai pada Candi Brahu tersaji pada tabel di bawah ini.

Tabe1 3 : Data kerusakan Candi Brahu akibat faktor kimia

\begin{tabular}{|c|c|c|c|c|c|}
\hline No. & Sisi & Bagian & Kerusakan & Jumlah (\%) & Keterangan \\
\hline \multirow[t]{3}{*}{1} & \multirow[t]{3}{*}{ Barat } & \multirow[t]{3}{*}{ Kaki I } & Penggaraman & 10 & \multirow{3}{*}{$\begin{array}{c}\text { Sebelah } \\
\text { selatan tangga }\end{array}$} \\
\hline & & & Mengelupas & 10 & \\
\hline & & & Rapuh & 80 & \\
\hline 2 & Barat & Kaki I & Rapuh & 10 & Tangga \\
\hline \multirow[t]{2}{*}{3} & \multirow[t]{2}{*}{ Barat } & \multirow[t]{2}{*}{ Kaki I } & Mengelupas & 10 & \multirow{2}{*}{$\begin{array}{c}\text { Sebelah utara } \\
\text { tangga }\end{array}$} \\
\hline & & & Rapuh & 35 & \\
\hline \multirow[t]{2}{*}{4} & \multirow[t]{2}{*}{ Barat } & \multirow[t]{2}{*}{ Kaki II } & Mengelupas & 5 & \\
\hline & & & Rapuh & 15 & \\
\hline 5 & Barat & Tubuh & Penggaraman & 10 & \\
\hline \multirow[t]{2}{*}{6} & \multirow[t]{2}{*}{ Barat } & \multirow[t]{2}{*}{ Atap } & Penggaraman & 15 & \\
\hline & & & Rapuh & 10 & \\
\hline \multirow[t]{2}{*}{7} & \multirow[t]{2}{*}{ Utara } & \multirow[t]{2}{*}{ Kaki I } & Mengelupas & 20 & \\
\hline & & & Rapuh & 35 & \\
\hline 8 & Utara & Kaki II & Rapuh & 10 & \\
\hline
\end{tabular}




\begin{tabular}{|c|c|c|c|c|}
\hline \multirow[t]{3}{*}{9} & \multirow[t]{3}{*}{ Utara } & \multirow[t]{3}{*}{ Tubuh } & Penggaraman & 15 \\
\hline & & & Mengelupas & 5 \\
\hline & & & Rapuh & 45 \\
\hline \multirow[t]{3}{*}{10} & \multirow[t]{3}{*}{ Utara } & \multirow[t]{3}{*}{ Atap } & Penggaraman & 10 \\
\hline & & & Mengelupas & 15 \\
\hline & & & Rapuh & 45 \\
\hline \multirow[t]{2}{*}{11} & \multirow[t]{2}{*}{ Timur } & \multirow[t]{2}{*}{ Kaki I } & Mengelupas & 20 \\
\hline & & & Rapuh & 55 \\
\hline \multirow[t]{2}{*}{12} & \multirow[t]{2}{*}{ Timur } & \multirow[t]{2}{*}{ Kaki II } & Mengelupas & 5 \\
\hline & & & Rapuh & 25 \\
\hline \multirow[t]{2}{*}{13} & \multirow[t]{2}{*}{ Timur } & \multirow[t]{2}{*}{ Tubuh } & Mengelupas & 5 \\
\hline & & & Rapuh & 60 \\
\hline \multirow[t]{2}{*}{14} & \multirow[t]{2}{*}{ Timur } & \multirow[t]{2}{*}{ Atap } & Mengelupas & 10 \\
\hline & & & Rapuh & 30 \\
\hline \multirow[t]{3}{*}{15} & \multirow[t]{3}{*}{ Selatan } & \multirow[t]{3}{*}{ Kaki I } & Penggaraman & 15 \\
\hline & & & Mengelupas & 15 \\
\hline & & & Rapuh & 75 \\
\hline 16 & Selatan & Kaki II & Mengelupas & 2 \\
\hline 17 & Selatan & Tubuh & Rapuh & 15 \\
\hline
\end{tabular}

Sumber : Dokumen Penulis

\section{Araldite Tar}

Bahan kimia yang juga diaplikasikan di Candi Brahu selama kegiatan pemugaran tahun 1991-1995 adalah Araldite tar. Pengolesan bahan ini terutama diaplikasikan pada bagian bawah bata yang dianggap lantai, batas bata hasil pemugaran tahap I dan tahap II, serta di atas dan samping lapisan cor beton. Berdasarkan Laporan Hasil Pelaksanaan Kegiatan Pemugaran Candi Brahu tahun 1991-1995 diperoleh data aplikasi bahan Araldite tar yang dapat disajikan pada tabel di bawah ini.

Tabel 4 : Data letak aplikasi bahan Araldite tar pada Candi Brahu

\begin{tabular}{|c|c|c|l|}
\hline No. & Tahap & Tahun & \multicolumn{1}{|c|}{ Bagian Candi yang Dioles } \\
\hline 1 & II & $1991 / 1992$ & Permukaan beton di bawah lapis 10 \\
\hline 2 & III & $1992 / 1993$ & Bagian atas beton, yaitu : di atas lapis 9 \\
\hline 3 & III & $1992 / 1993$ & Bagian bawah bata yang dianggap lantai \\
\hline 4 & III & $1992 / 1993$ & $\begin{array}{l}\text { Kaki I di atas bata lapis 49 sisi barat, utara, } \\
\text { timur, dan selatan }\end{array}$ \\
\hline 5 & III & $1992 / 1993$ & $\begin{array}{l}\text { Kaki II di atas lapis 73 sisi barat, utara, } \\
\text { timur, dan selatan }\end{array}$ \\
\hline 6 & III & $1992 / 1993$ & $\begin{array}{l}\text { Bata isian kaki I tahap II yang berimpitan } \\
\text { dengan dinding kaki I tahap I, yaitu : bata } \\
\text { lapis 20 - 50 }\end{array}$ \\
\hline 7 & III & $1992 / 1993$ & $\begin{array}{l}\text { Bata isian kaki I tahap I yang dipotong, yaitu } \\
\text { : bata lapis 9 - 19 }\end{array}$ \\
\hline 8 & III & $1992 / 1993$ & $\begin{array}{l}\text { Lantai kaki I sisi barat, utara, timur, dan } \\
\text { selatan }\end{array}$ \\
\hline 9 & III & $1992 / 1993$ & $\begin{array}{l}\text { Lantai kaki II sisi barat, utara, timur, dan } \\
\text { selatan }\end{array}$ \\
\hline 10 & III & $1992 / 1993$ & $\begin{array}{l}\text { Bata isian kaki I sisi barat, utara, timur, dan } \\
\text { selatan, yaitu : lapis 46 - 50 }\end{array}$ \\
\hline 11 & IV & $1993 / 1994$ & $\begin{array}{l}\text { Bata baru pola acak di sekitar bata asli yang } \\
\text { tidak berprofil di bagian tubuh bawah }\end{array}$ \\
\hline 13 & IV & $1993 / 1994$ & $\begin{array}{l}\text { Bata susunan Belanda yang permukaannya } \\
\text { rusak }\end{array}$ \\
\hline
\end{tabular}

\section{AC 322 dan Hyvar XL}

Untuk aplikasi bahan AC 322 dan Hyvar XL, dalam Laporan Hasil Pelaksanaan Kegiatan Pemugaran menyebutkan bahwa aplikasi kedua bahan tersebut hanya dilakukan pada tahap III di bagian tubuh sisi barat, utara, timur, dan selatan sedangkan aplikasi pada bagian lain dari bangunan candi tidak ditemukan datanya. Pada tahap I, II, IV, dan V tidak tertulis adaya penggunaan kedua bahan tersebut.

Hasil observasi jenis kerusakan yang paling banyak dijumpai di Candi Brahu selain akibat faktor kimia adalah akibat faktor biologi berupa pertumbuhan tanaman tingkat rendah (berupa : lumut, alga, dan lichenes) serta tanaman tingkat tinggi (berupa : pakupakuan, Kersen, dan lain-lain). Data kerusakan akibat faktor biologi yang terjadi di Candi Brahu dapat disajikan pada tabel di bawah ini.

Tabel 5 : Data kerusakan di Candi Brahu akibat faktor biologi

\begin{tabular}{|c|c|c|c|c|c|}
\hline No. & Sisi & Bagian & Kerusakan & Jumlah (\%) & \multirow{2}{*}{ Keterangan } \\
\hline 1 & Barat & Kaki I & Lumut & 20 & \multirow{2}{*}{ Sebelah } \\
selatan tangga
\end{tabular}

Sumber : Laporan Pemugaran Candi Brahu 


\begin{tabular}{|c|c|c|c|c|c|}
\hline & & & $\begin{array}{l}\text { Tumbuhan } \\
\text { tingkat tinggi }\end{array}$ & 45 & \\
\hline \multirow[t]{3}{*}{11} & \multirow[t]{3}{*}{ Timur } & \multirow[t]{3}{*}{ Kaki I } & Lumut & 10 & \\
\hline & & & Alga & 20 & \\
\hline & & & Lichenes & 5 & \\
\hline \multirow[t]{2}{*}{12} & \multirow[t]{2}{*}{ Timur } & \multirow[t]{2}{*}{ Kaki II } & Lumut & 10 & \\
\hline & & & Alga & 15 & \\
\hline \multirow[t]{4}{*}{13} & \multirow[t]{4}{*}{ Timur } & \multirow[t]{4}{*}{ Tubuh } & Lumut & 10 & \\
\hline & & & Alga & 20 & \\
\hline & & & Lichenes & 5 & \\
\hline & & & $\begin{array}{l}\text { Tumbuhan } \\
\text { tingkat tinggi }\end{array}$ & 20 & \\
\hline \multirow[t]{2}{*}{14} & \multirow[t]{2}{*}{ Timur } & \multirow[t]{2}{*}{ Atap } & Alga & 20 & \\
\hline & & & $\begin{array}{l}\text { Tumbuhan } \\
\text { tingkat tinggi }\end{array}$ & 20 & \\
\hline \multirow[t]{4}{*}{15} & \multirow[t]{4}{*}{ Selatan } & \multirow[t]{4}{*}{ Kaki I } & Lumut & 30 & \\
\hline & & & Alga & 40 & \\
\hline & & & Lichenes & 10 & \\
\hline & & & $\begin{array}{l}\text { Tumbuhan } \\
\text { tingkat tinggi }\end{array}$ & 5 & \\
\hline \multirow[t]{3}{*}{16} & \multirow[t]{3}{*}{ Selatan } & \multirow[t]{3}{*}{ Kaki II } & Lumut & 15 & \\
\hline & & & Alga & 5 & \\
\hline & & & Lichenes & 5 & \\
\hline \multirow[t]{4}{*}{17} & \multirow[t]{4}{*}{ Selatan } & \multirow[t]{4}{*}{ Tubuh } & Lumut & 25 & \\
\hline & & & Alga & 40 & \\
\hline & & & Lichenes & 50 & \\
\hline & & & $\begin{array}{l}\text { Tumbuhan } \\
\text { tingkat tinggi }\end{array}$ & 20 & \\
\hline \multirow[t]{4}{*}{18} & \multirow[t]{4}{*}{ Selatan } & \multirow[t]{4}{*}{ Atap } & Lumut & 25 & \\
\hline & & & Alga & 35 & \\
\hline & & & Lichenes & 55 & \\
\hline & & & $\begin{array}{l}\text { Tumbuhan } \\
\text { tingkat tinggi }\end{array}$ & 30 & \\
\hline
\end{tabular}

\section{Analisis Data}

Berdasarkan hasil observasi terhadap tiga jenis bata penyusun Candi Brahu, yaitu : bata lama, bata hasil pemugaran Belanda, dan bata hasil pemugaran tahun 1991-1995 terlihat perbedaan yang cukup signifikan ditinjau dari warna bata, kekuatannya, dan ketahanannya terhadap pengaruh lingkungan. Sepintas mungkin terlihat sama, namun apabila diamati lebih dalam akan terlihat perbedaannya. Bata lama terlihat padat, berwarna merah kecoklatan, dan sebagian struktur bata tidak terlihat natnya. Meskipun di beberapa penampil bagian kaki I terlihat rapuh hingga bentuknya sudah tidak utuh lagi, namun kerapuhan tersebut tidak meninggalkan serbuk bata ketika disentuh.
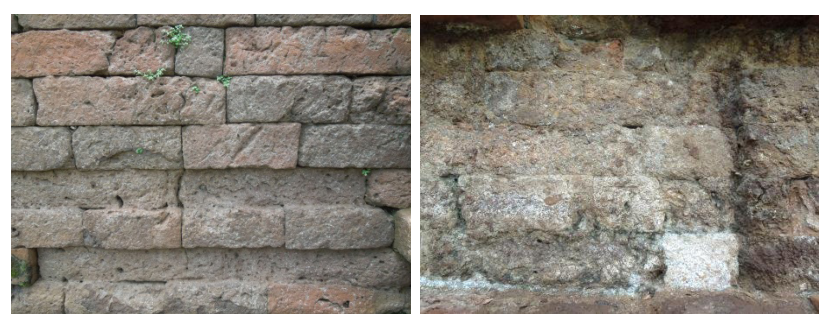

Foto 2. Kondisi bata lama yang utuh (kiri) dan

\section{rapuh (kanan)}

Sumber : Dokumentasi penulis

Bata hasil pemugaran Belanda juga terlihat padat, berwarna merah kecoklatan, terdapat spesi berwarna abuabu, dan nat antar bata agak lebar. Bata ini belum terlihat rapuh meskipun sebagian bata terkena lapisan spesi yang mengandung unsur kalsium (Ca), namun batanya tidak mengalami penggaraman.
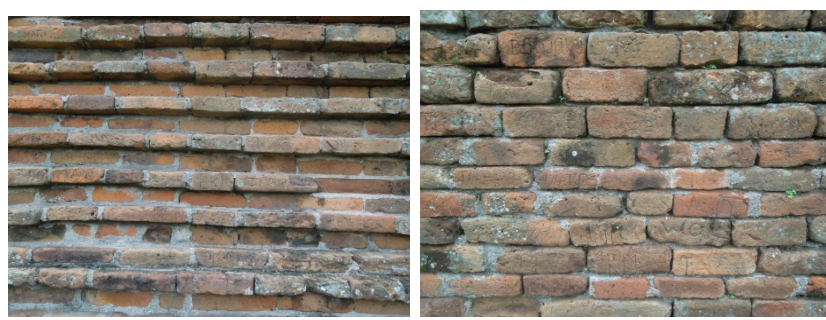

Foto 3. Struktur bata hasil pemugaran Belanda

Sumber: Dokumentasi penulis

Berbeda dengan bata lama dan bata hasil pemugaran Belanda, bata hasil pemugaran tahun 1991-1995 cenderung mudah mengelupas dan rapuh, berwarna oranye tua, serta terdapat spesi berwarna abuabu. Hampir sebagian besar struktur yang menggunakan bata ini mengalami kerapuhan yang apabila disentuh akan meninggalkan serbuk bata pada permukaan tangan. Proses kerapuhan bata terjadi cukup cepat hingga beberapa struktur bata sudah tidak terlihat bentuknya. Selain itu, bata juga cenderung mengalami penggaraman yang akhirnya mengelupas dan rapuh.
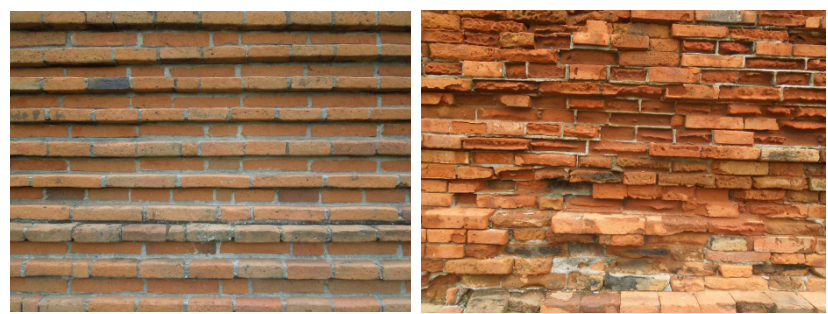

Foto 4. Kondisi bata hasil pemugaran tahun 19911995 yang utuh (kiri) dan rapuh (kanan)

Sumber : Dokumentasi penulis

Dalam kegiatan evaluasi pasca pemugaran Candi Brahu, pendataan tidak hanya dilakukan pada jenis bata penyusunnya tetapi juga dampak dari penggunaan bahan kimia pada struktur bata tersebut. Analisis pengaruh aplikasi bahan kimia selama kegiatan pemugaran tahun 1991-1995 dapat dijelaskan sebagai berikut :

\section{Silicosol}


Silicosol hanya diaplikasikan pada permukaan bata bagian kaki I dan kaki II. Seperti telah dijelaskan di atas bahwa Silicosol dapat menimbulkan dampak negatif pada struktur bata apabila masalah kapilarisasi air belum tertangani dengan baik. Dampak yang dapat terlihat adalah munculnya kerusakan berupa penggaraman akibat terakumulasinya mineral garam di permukaan bata yang akhirnya menimbulkan pengelupasan dan kerapuhan. Ketiga kerusakan tersebut dapat dikategorikan sebagai kerusakan akibat faktor kimia.

Dari hasil pengamatan kerusakan pada permukaan bata akibat faktor kimia berupa penggaraman, pengelupasan, dan kerapuhan di kaki I, kaki II, tubuh, dan atap sisi barat, utara, timur, dan selatan diperoleh data sebagai berikut :

a. Penggaraman

Kerusakan berupa penggaraman terlihat pada struktur bata lama dan bata hasil pemugaran tahun 1991-1995. Namun bata hasil pemugaran tahun 19911995 kuantitas penggaramannya lebih banyak dibanding bata lama. Berdasarkan hasil observasi diketahui bahwa penggaraman pada bata hasil pemugaran tahun 19911995 terlihat di kaki I, tubuh, dan atap sisi barat; tubuh dan atap sisi utara; dan kaki I sisi selatan sedangkan bata lama mengalami penggaraman di kaki I dan tangga sebelah selatan sisi barat serta kaki I sisi selatan.
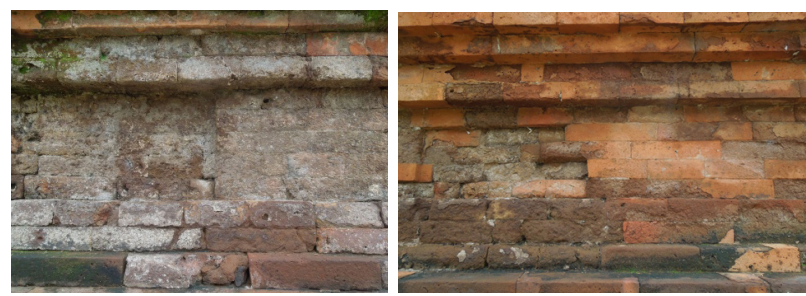

Foto 5. Bata lama (kiri) dan bata baru (kanan) yang mengalami penggaraman

Sumber : Dokumentasi penulis

Struktur bata di sisi utara dan barat cenderung mengalami penggaraman disebabkan letaknya selalu terpapar sinar matahari yang intensitasnya lebih tinggi dibanding sisi lainnya. Berdasarkan hasil pengukuran suhu dan kelembaban udara di halaman Candi Brahu menunjukkan bahwa ketika matahari mulai terik sekitar pukul 10.00-14.00 suhu udara berkisar antara 34,4-45 ${ }^{\circ} \mathrm{C}$ dengan kelembaban udara berkisar antara 43-61\%. Nilai suhu udara cenderung tinggi terutama di sisi barat dan utara sedangkan sisi timur dan selatan cenderung lebih rendah.

Selain faktor intensitas sinar matahari, penggunaan semen yang mengandung unsur kalsium disertai adanya air hujan dan angin juga menjadi faktor penyebab munculnya penggaraman. Tidak hanya akibat faktor lingkungan, penggaraman pada bata juga dimungkinkan terjadi karena faktor internal, yaitu : dari dalam bata itu sendiri. Apabila campuran bahan yang digunakan untuk membuat bata mengandung unsur kalsium cukup banyak, maka bata yang dihasilkannya pun akan cepat mengalami penggaraman.

Penggaraman bata di Candi Brahu terlihat lebih banyak terjadi pada bata hasil pemugaran tahun 1991-1995. Ini menandakan kualitas bata tersebut lebih rendah dibandingkan bata lama dan bata hasil pemugaran Belanda yang juga menggunakan semen sebagai spesi perekat antar bata. Selain muncul penggaraman, bata hasil pemugaran tahun 1991-1995 memiliki warna yang lebih cerah dan cenderung rapuh. Dengan demikian munculnya penggaraman bata di candi ini disebabkan oleh kualitas bata yang kurang bagus dan bukan karena penggunaan bahan kimia selama kegiatan pemugaran.

\section{b. Pengelupasan}

Pengelupasan merupakan proses awal terjadinya kerapuhan bata. Berdasarkan hasil observasi diketahui bahwa kerusakan bata berupa pengelupasan lebih banyak terjadi pada bata hasil pemugaran tahun 1991-1995 terutama bagian pelipit di kaki I. Selain kaki I seluruh sisi, pengelupasan bata juga terjadi pada kaki II sisi barat, selatan, dan timur serta tubuh sisi timur dan utara. Pengelupasan juga terjadi pada bata lama di bagian atap sisi timur dan utara namun kuantitasnya sedikit.
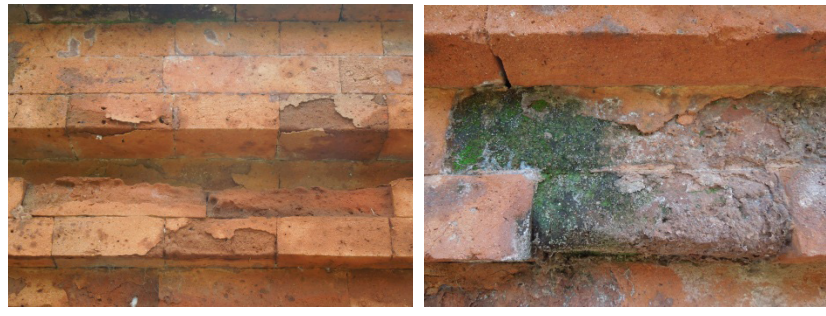

Foto 6. Pengelupasan bata pada bagian pelipit

(kiri) dantumbuhnya lumut pada bata yang mengelupas (kanan)

Sumber : Dokumentasi penulis 
Bagian pelipit pada kaki I merupakan posisi yang sering mengalami kerusakan berupa pengelupasan yang utamanya terjadi pada bata hasil pemugaran tahun 19911995. Bagian pelipit yang membentuk sudut ke dalam struktur menyebabkan air hujan tertahan pada cekungan tersebut sehingga kelembaban bata meningkat. Dampak dari meningkatnya kelembaban bata adalah tumbuhnya tanaman tingkat rendah, seperti : lumut, alga, dan lichenes. Selain menjadi media yang baik bagi pertumbuhan tanaman, bata yang lembab juga menyebabkan porositas meningkat sehingga lebih mudah mengikat molekul air. Apabila kondisi ini tidak segera dilakukan penanganan, maka bata akan menjadi rapuh.

Bata hasil pemugaran tahun 1991-1995 lebih banyak mengalami pengelupasan dibanding bata lama dan bata hasil pemugaran Belanda. Mengingat pengolesan bahan pelindung berupa Silicosol dilakukan di seluruh permukaan bata di bagian kaki I, kaki II, dan sebagian tubuh, maka pengelupasan bata pada candi ini tidak disebabkan oleh pengaruh bahan kimia melainkan karena jenis bata yang digunakan pada pemugaran tahun 1991-1995 yang kualitasnya kurang bagus.

\section{c. Kerapuhan}

Berbeda dengan pengelupasan yang hanya terjadi pada bata hasil pemugaran tahun 1991-1995, kerusakan berupa rapuh terjadi baik pada bata lama maupun bata hasil pemugaran tahun 1991-1995. Utamanya, kerapuhan terjadi pada bata di bagian kaki I, sebagian kaki II, tubuh, dan atap baik di sisi barat, utara, timur, dan selatan. Bata yang mengalami kerapuhan lebih sering dijumpai pada struktur berbentuk pelipit dan bagian bidang yang berada di bawahnya. Kondisi struktur bata pada kaki II sisi barat relatif utuh karena tidak ada bentuk pelipit.
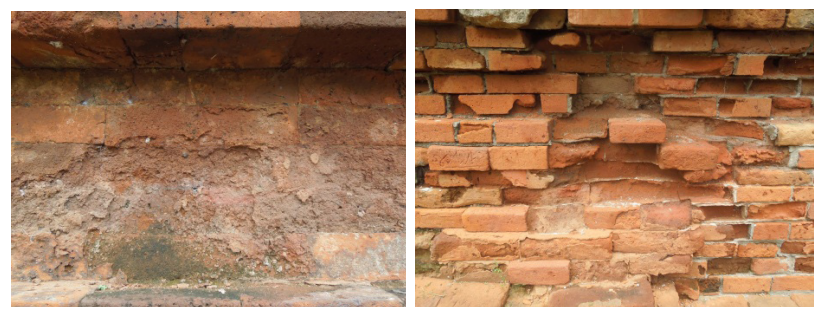

Foto 7. Kerapuhan pada bata lama (kiri) dan bata hasil pemugaran tahun 1991-1995 (kanan)

Sumber : Dokumentasi penulis
Kerapuhan bata di Candi Brahu kemungkinan besar diakibatkan oleh pengaruh lingkungan dan pengaruh dari dalam bata. Pengaruh lingkungan dapat berupa air hujan, sinar matahari, dan angin sedangkan pengaruh dari dalam bata disebabkan oleh faktor usia atau adanya penambahan bahan tertentu ketika proses pembuatannya. Kerapuhan pada bata lama terjadi karena faktor usia mengingat Candi Brahu didirikan sekitar abad XIII-XV M. Namun yang menjadi masalah adalah bata hasil pemugaran tahun 1991-1995 yang cenderung rapuh menandakan adanya ketidaksesuaian baik dari komposisi bahan maupun proses pembuatannya.

Selama kegiatan pemugaran tahun 1991-1995, sebagian permukaan kaki I dan kaki II dioles dengan bahan pelindung berupa Silicosol. Aplikasi bahan ini dilakukan pada permukaan bata baik bata lama, bata hasil pemugaran Belanda, maupun bata hasil pemugaran tahun 1991-1995. Namun, dari hasil observasi menunjukkan bahwa kerapuhan bata hanya didominasi oleh bata hasil pemugaran tahun 1991-1995 meskipun beberapa bata lama juga mengalaminya. Ini menandakan bahwa kerupuhan yang terjadi pada bata Candi Brahu bukan disebabkan oleh pengaruh bahan Silicosol tetapi karena bata pengganti yang dipilih selama kegiatan pemugaran tahun 1991-1995 yang kurang berkualitas.

\section{Araldite Tar}

Dari hasil pengamatan bata yang terletak di bagian lantai kaki I dan kaki II serta di atas lapisan cor beton tidak menunjukkan adanya kerusakan hanya sedikit mengelupas akibat faktor lingkungan mengingat letaknya yang horizontal sehingga memungkinkan air hujan tergenang pada lantai tersebut. Bata yang berada di atas lapisan cor beton juga terlihat utuh meskipun tertutup tanah. Foto kondisi lantai dan bata di atas lapisan cor beton dapat dilihat di bawah ini. 

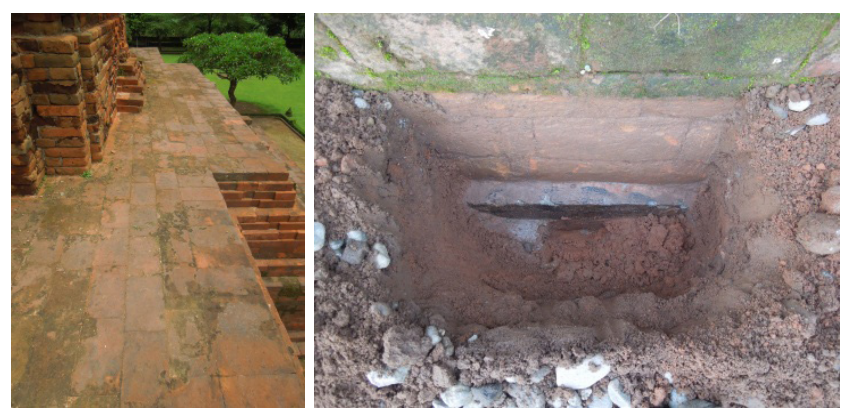

Foto 8. Kondisi lantai Kaki II (kiri) dan struktur bata di atas lapisan cor beton (kanan)

Sumber : Dokumentasi penulis

Setelah lebih dari 20 tahun, kondisi lantai dan struktur bata di atas lapisan cor beton relatif utuh. Ini menunjukkan bahwa bahan Araldite yang diaplikasikan saat itu cukup efektif untuk mencegah resapan air hujan dan kapilarisasi air tanah sehingga tidak menimbulkan kerusakan pada struktur bata.

\section{AC 322 dan Hyvar XL}

Efektivitas bahan AC 322 dan Hyvar XL yang diaplikasikan pada bangunan cagar budaya yang berada di lingkungan terbuka tidak mampu bertahan lama. Hal ini terjadi karena pelarut dari kedua bahan tersebut adalah air. Menurunnya efektivitas bahan kimia menyebabkan bata rentan mengalami pertumbuhan tanaman tingkat rendah.

Mengingat efektivitas bahan AC 322 dan Hyvar XL tidak dapat bertahan dalam waktu lama, maka hasil pengamatan yang dilakukan selama kegiatan evaluasi pasca pemugaran Candi Brahu tidak dapat digunakan untuk mengevaluasi dampak dari penggunaan kedua bahan tersebut. Tumbuhnya tanaman tingkat rendah, seperti : lumut, alga, dan lichenes serta tanaman tingkat tinggi, seperti : paku-pakuan pada bangunan candi kemungkinan besar disebabkan tingkat porositas bata yang cukup tinggi sehingga mudah mengikat air. Kemudahannya dalam mengikat air menyebabkan bata cenderung lembab dan ini merupakan media yang baik bagi pertumbuhan tanaman.
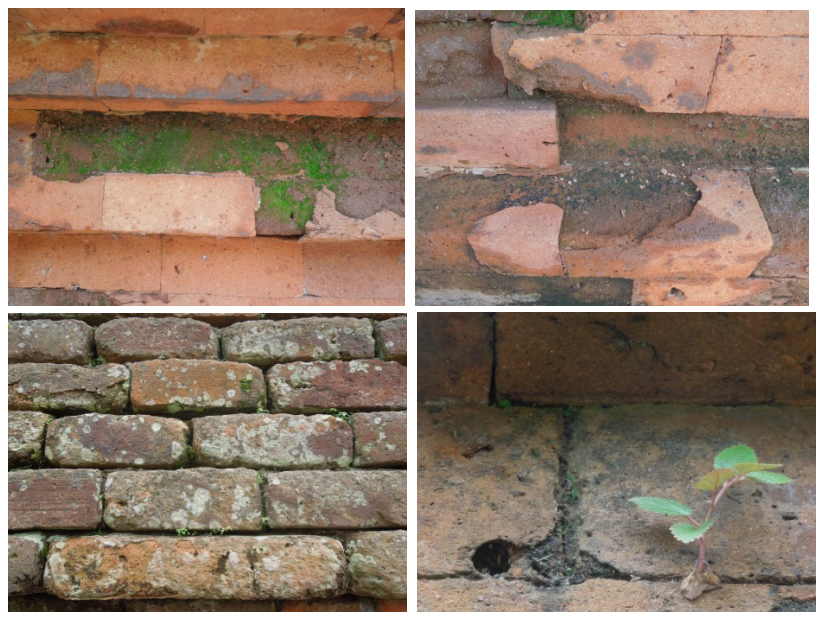

Foto 9. Pertumbuhan lumut dan alga (atas) serta pertumbuhan lichenes dan tanaman tingkat tinggi (bawah)

Sumber : Dokumentasi penulis

Kegiatan konservasi untuk menghambat pertumbuhan tanaman tingkat rendah dan tanaman tingkat tinggi telah dilaksanakan pada tahun 2017 terutama bagian kaki I dan kaki II seluruh sisi sedangkan bagian tubuh dan atap belum dikonservasi. Kegiatan konservasi saat itu bertepatan dengan musim penghujan. Inilah yang menjadi penyebab munculnya kembali lumut, alga, dan tanaman tingkat tinggi pada bagian kaki I dan kaki II sedangkan pesatnya pertumbuhan lichenes pada bagian tubuh dan atap disebabkan belum tuntasnya kegiatan konservasi.

Meskipun kerusakan yang terjadi di Candi Brahu lebih banyak disebabkan oleh faktor kimia dan biologi, namun kerusakan akibat faktor fisik berupa aus juga dijumpai pada tangga sisi barat sejumlah 45\%. Selain itu, kerusakan akibat faktor manusia berupa vandalisme juga tampak pada bagian Tubuh candi sisi barat sejumlah $5 \%$ dan sisi timur sejumlah $10 \%$. Munculnya berbagai kerusakan ini tidak terlepas dari pengaruh lingkungan baik yang bersifat biotik maupun abiotik. Pengaruh biotik dapat berasal dari manusia, hewan, dan tumbuhan sedangkan pengaruh abiotik dapat berupa suhu dan kelembaban udara, iklim, angin, sinar matahari, hujan, dan bencana alam. Dengan demikian upaya pelestarian melalui kegiatan konservasi perlu dilakukan secara berkala untuk mencegah kerusakan semakin meluas. 


\section{PENUTUP}

\section{A. Simpulan}

Berdasarkan hasil evaluasi dampak penggunaan bahan kimia selama kegiatan pemugaran Candi Brahu dapat disimpulkan bahwa :

1. Bata penyusun bangunan candi terdiri dari tiga jenis, yaitu : bata lama, bata hasil pemugaran Belanda, dan bata hasil pemugaran tahun 1991-1995. Bata lama dan bata hasil pemugaran Belanda memiliki karakteristik warna yang sama dan padat, namun bata hasil pemugaran tahun 1991-1995 terlihat warnanya lebih cerah dan cenderung rapuh.

2. Kerusakan bata berupa penggaraman, pengelupasan, dan kerapuhan yang terjadi pada bangunan candi terutama bata hasil pemugaran tahun 1991-1995 bukan disebabkan aplikasi bahan Silicosol tetapi karena kualitas bata yang kurang bagus dan posisi struktur yang membentuk sudut ke dalam.

3. Bahan Araldite tar yang diaplikasikan pada bagian tertentu dari bangunan tidak menimbulkan dampak negatif. Ini mengartikan bahwa bahan ini efektif untuk mencegah resapan air hujan dan kapilarisasi air tanah.

4. Pertumbuhan tanaman yang didata saat kegiatan evaluasi tidak dapat dijadikan sebagai acuan dalam menentukan dampak aplikasi bahan AC 322 dan Hyvar XL karena efektivitasnya tidak dapat bertahan lama.

\section{B. Saran}

Dalam menjaga eksistensi bangunan cagar budaya Candi Brahu, maka upaya yang dapat dilakukan :

1. Kegiatan evaluasi dampak penggunaan bahan kimia sebaiknya tidak hanya dilakukan setelah kegiatan pemugaran saja tetapi evaluasi juga perlu dilakukan setelah kegiatan konservasi.

2. Kerusakan berupa pengelupasan dan kerapuhan terutama yang terjadi pada bagian pelipit candi perlu dicarikan solusi penanganan agar tidak semakin meluas.

3. Melihat kondisi bata hasil pemugaran tahun 19911995 yang kurang berkualitas, maka perlu dilakukan kajian untuk menentukan komposisi bata yang berkualitas sebagai pengganti bata tersebut yang rusak.

Dengan demikian diharapkan kerusakan yang terjadi pada Candi Brahu dapat dicegah sehingga kelestariannya tetap terja 


\section{DAFTAR PUSTAKA}

Anonim. 2015. DuPont Hyvar X-L Herbicide. Material Safety Data Sheet. Canada : E.I. du Pont Canada Company.

Anonim. 2017. Silicosol. https://pubchem.ncbi.nlm.nih. gov diakses tanggal 28 Mei 2018.

Anonim. 2017. Araldite Tar. http://borobudurpedia.id/ artikel/araldite-tar-466 diakses tanggal $30 \mathrm{Mei}$ 2018.

Cahyandaru, Nahar. 2013. Konservasi Cagar Budaya Bata. Makalah Bimbingan Teknis Konservasi Tingkat Menengah. Magelang : Balai Konservasi Borobudur.

Ismangil dan Eko Hanudin. 2005. Degradasi Mineral Batuan Oleh Asam-asam Organik. Jurnal Ilmu Tanah dan Lingkungan Vol 5 (1) (2005) p : 1 -17 .

Kanunov, A.E., A.I. Orlova, and V.T. Demarin. 2013. Synthesis And Investigation Of CalciumContaining Phosphatosilicates With NaZr2(PO4)3 Structure. Russian Journal Of General Chemistry, 2013, Vol. 83, No.6, pp. 1029-1034 : Pleiades Publishing Ltd.

Muhammad, Rony; Nahar Cahyandaru; dan Heri Yulianto. 2010. Laporan Hasil Kajian Evaluasi Penggunaan Epoxy Resin pada Candi Borobudur. Magelang : Balai Konservasi Peninggalan Borobudur. Direktorat Jenderal Sejarah dan Purbakala. Kementerian Kebudayaan dan Pariwisata.

Rini, Dewi Puspito. 2013. Conservation Efforts In Indonesia's Cultural Heritage. Research, Analysis, and Preservation of Archaeological Sites and Remains. Training Course on Cultural Heritage Protection In The Asia Pasific Region 2012. Japan : Cultural Heritage Protection Cooperation Office, Asia - Pacific Cultural Centre For UNESCO (ACCU).

Tim. 1992. Laporan Hasil Pelaksanaan Kegiatan Proyek Pelestarian/Pemanfaatan Peninggalan Sejarah dan Purbakala Bekas Kota Kerajaan Majapahit. Tahun Anggaran 1991/1992. Direktorat Perlindungan dan Pembinaan Peninggalan
Sejarah dan Purbakala. Direktorat Jenderal Kebudayaan. Departemen Pendidikan dan Kebudayaan.

Tim. 1993. Laporan Hasil Pelaksanaan Kegiatan Proyek Pelestarian/Pemanfaatan Peninggalan Sejarah dan Purbakala Bekas Kota Kerajaan Majapahit. Tahun Anggaran 1991/1992. Direktorat Perlindungan dan Pembinaan Peninggalan Sejarah dan Purbakala. Direktorat Jenderal Kebudayaan. Departemen Pendidikan dan Kebudayaan.

Tim. 1994. Laporan Hasil Pelaksanaan Kegiatan Proyek Pelestarian/Pemanfaatan Peninggalan Sejarah dan Purbakala Bekas Kota Kerajaan Majapahit. Tahun Anggaran 1991/1992. Direktorat Perlindungan dan Pembinaan Peninggalan Sejarah dan Purbakala. Direktorat Jenderal Kebudayaan. Departemen Pendidikan dan Kebudayaan.

Tim. 1995. Laporan Hasil Pelaksanaan Kegiatan Unit Pemugaran Candi Brahu Bulan Maret 1995. Bagian Proyek Pelestarian/Pemanfaatan Peninggalan Sejarah dan Purbakala Bekas Kota Kerajaan Majapahit. Tahun Anggaran 1991/1992. Direktorat Perlindungan dan Pembinaan Peninggalan Sejarah dan Purbakala. Direktorat Jenderal Kebudayaan. Departemen Pendidikan dan Kebudayaan.

Tim. 2017. Kajian Zonasi Kawasan Cagar Budaya Trowulan. Mojokerto : Balai Pelestarian Cagar Budaya Jawa Timur. Direktorat Pelestarian Cagar Budaya dan Permuseuman. Direktorat Jenderal Kebudayaan. Kementerian Pendidikan dan Kebudayaan.

Ul'yanova, T.M. and N.P. Krut'ko. 2004. Influence of Oxidazing Media on The Properties of CarbonBased Fibrous Materials With Protective Coatings. Journal of Engineering Physics and Thermophysics, Vol. 77, No. 3, 2004 : Plenum Publishing Corporation.

Undang Undang Republik Indonesia Nomor 11 Tahun 2010 Tentang Cagar Budaya. 